\title{
Creativity and 21st Century Soft Skills Development Opportunities in Education of Top Management in International Environment
}

DOI $10.18267 /$ pr.2021.krn.4816.22

\author{
Anna Veszprémi Sirotková ${ }^{1}$ - Veronika Orfánusová ${ }^{2}$ \\ ORCID iD: 0000-0001-7444-1165 ${ }^{1}, 0000-0001-8733-6129^{2}$ \\ anna.veszpremi@euba.sk; veronika.nekolova@euba.sk \\ ${ }^{1}$ University of Economics in Bratislava, Faculty of Commerce, Department of Services \\ and Tourism, \\ Bratislava, Slovakia \\ ${ }^{2}$ University of Economics in Bratislava, Faculty of Commerce, Department of \\ Marketing \\ Bratislava, Slovakia
}

\begin{abstract}
Ongoing political, economic, social and technological changes all over the world require higher demands on skills of top managers, they must be more flexible and more adaptable than ever before. Can Design Thinking lead to better solutions to such problems, especially from a managerial perspective? This article presents results from an exploratory case study, where the managers from 7 universities participated in soft skills training using the design thinking methods. The study proved that managers who used a design thinking approach seemed to be more competent to understand creativity, teamwork and interdisciplinarity at finding new solutions. The aim of our contribution is to introduce our knowledge and experience with creativity and other soft skills development opportunities in education of top management in the international environment. The present study is part of a larger research project on the application of design thinking as an approach to finding creative solutions to problems.
\end{abstract}

Keywords: design thinking, creativity, team work, case study, management

JEL Classification codes: A20, I23, J24, O30

\section{INTRODUCTION}

World Economic Forum (2019) defined 10 top demanded soft skills for our recent and future workforce: complex problem solving, critical thinking, creativity, people management, coordinating with others, emotional intelligence, judgment and decision-making, service orientation, negotiation and cognitive flexibility. The importance of this challenge is the fact, that this topic is discussed at several other international institutions, such as European Commission and OECD.

The OECD co- operates with member countries to develop policy responses that are tailored to each country's specific skills needs. The outcome of this approach is the OECD Skills Strategy Framework, which points to what countries can do better to develop relevant skills over the life course; to use skills effectively in work and in society; and to strengthen the governance of the skills system (OECD, 2020).

The process of modernization of education systems is based on quality of university management and staff - top managers, that create policy, corporate culture and working 
conditions for all others, curriculums and study programs, administration staff, which is responsible for smooth realization of all processes, and teachers, responsible for teaching process. They face a lot of challenges, such as international competition, lack of sources, uncertain environment, etc. Development of their soft skills will lead to their more effective work, to higher level of corporate culture, better working atmosphere, more satisfied employees and to better results.

Many business and innovation managers and academics have been calling attention to the need for changes in business school curricula and learning methods, prompted by the continual social and economic transformation (Martin, 2009; Dunne, 2009; Glen et al., 2014).

\section{LITERATURE REVIEW}

The European Commission support the development of higher education policies in EU countries in line with the Education and Training 2020 strategy (ET2020) and works closely with policy makers. The renewed EU agenda for higher education, adopted by the Commission in May 2017, identifies four key goals for European cooperation in higher education:

- tackling future skills mismatches and promoting excellence in skills development;

- $\quad$ building inclusive and connected higher education systems;

- $\quad$ ensuring higher education institutions contribute to innovation;

- supporting effective and efficient higher education systems. (European Commission, 2020)

With the aim to help achieve these goals, the Commission proposed specific actions at EUlevel, primarily supported by different strands of the Erasmus+ and Horizon 2020 programs. In particular, the European Commission supports:

- the exchange of good policy practices between different countries through the ET2020 higher education working group;

- the Bologna Process - designed to promote the internationalization of higher education in Europe. Through more mobility, easier recognition of qualifications and streamlined quality assurance mechanisms;

- the development and use of mobility and recognition tools, such as the ECTS system and the Diploma Supplement, to increase transparency and facility exchanges in Europe (European Commission, 2020).

The European Commission in the area of education has taken a number of further initiatives, e.g. the concept of Networks of European Universities, that brings a significant change to higher education practices through integrated curricula and mobility, Council recommendation on automatic mutual recognition of higher education and school leaving diplomas, that helps to support students mobility and the future European Student Card, that will facilitate the secure exchange of student information and reduce administrative burden for higher education institutions. These initiatives will help to foster quality, excellence, and innovation in educational systems, that will prepare new generation of young people better prepared for the needs of new challenges, that will occur. Excellent and innovative educational systems consist of institutions, educational facilities, and networks, where all of them need excellent and innovative management staff, that also need to have necessary hard and soft skills, that can be further developed.

There are a number of tools and methods that support creative thinking and soft skills for example "problem-based learning, design thinking, project based learning". Design thinking is defined as "a creative problem-solving process that focuses on understanding the needs of others, rapid testing and iterating, and bringing out your inner creative genius". (Tran, 2019) In this process is crucial to support users in their development of creativity, that is "the ability 
to make or otherwise bring into existence something new, whether a new solution to a problem, a new method or device, or a new artistic object or form". (Kerr, 2019). Design thinking has emerged as a powerful new problem-solving approach and it's used in public and private sectors for solving tomorrow's problems.

Creativity is an essential skill based on expected engineering competency, as well as on the impact of engineering on society and on the environment (Paul, R., Hugo, R.J. and Falls, L.C., 2016). A creative person is able to produce a wide range of ideas, processes or products that are novel, original, unexpected, imaginative or useful, as well as recognizing limitations and constraints. (Pusca and Northwood, 2018) Creativity plays a significant role in problem-solving, where students can muster their experiences in the context of social cognitive theory, and therefore create a strong sense of efficacy (Dinther, Dochy, Segers, 2011).

Creativity is related to imagination or original ideas to create something through various thinking techniques. The reason why people are motivated to be creative is there is a need for novel, varied and complex stimulation. The second reason is there is a need to communicate ideas and values and the third reason is there is a need to solve the problem. (Khairul, 2020)

More specifically, creativity was flagged as a competency in students who demonstrated indicators like originality, open-mindedness, flexibility and divergent thinking. That design thinking students came up with more creative solutions echoes findings from numerous studies, which have highlighted the positive effects of design thinking on creativity (Cassim, 2013; Renard, 2014).

Design is a course of action for the development of an artifact or a system of artifacts. It is a process of realization of the idea to form or product that have artistic added value, strength, function, solving user problems and applying technology for the products or the production process (Khairul, 2020).

\section{Design Thinking}

The combination of the terms "thinking" and "design", offers fields such as Innovation Management the opportunity to apply design tools to other problem-solving-contexts like for example to businesses, services, and processes. Today, Design Thinking is understood as a way of thinking which leads to transformation, evolution, and innovation, to new forms of living and to new ways of managing business (Tschimmel, 2012).

Design Thinking relies on the designer's capacity to consider at the same time 1 . human needs and new visions of living well, 2. available material and technical resources, and 3. the constrains and opportunities of a project or business. The integration of these three factors demands from the designer, the ability to be at the same time analytical and emphatic, rational and emotional, methodical and intuitive, oriented by plans and constraints, but spontaneous (Pombo, Tschimmel, 2005). Some design researchers call this kind of dualistic reasoning designers' use 'abductive thinking' to differentiate it from the rational deductive and inductive reasoning (Martin, 2009; Cross, 2011) Design Thinking can also be considered as a manifestation of collective intelligence, whereby important consideration is given to the human being, to his or her behaviour and needs, and wherein creativity among participating problem solvers frequently challenges previously suggested solutions (Pruneau, El Jai, Dionne, Louis, Potvin, 2019).

According to Brown and Sheer $(2009,2013)$ Design Thinking process has the six steps:

1. Observation-inspiration: an ethnographic survey is conducted, while demonstrating empathy for the people affected by the issue (the users), as well as for the problem they are experiencing. 
2. Definition-synthesis: the problem is defined and redefined through an iterative process. The goal is to learn information and gain insight into various perspectives surrounding the issue. The information is briefly summarized.

3. Ideation: many ideas are proposed and some of them are retained, while others are discarded.

4. Prototyping: prototypes are very quickly built to emphasize the different ideas that have been generated.

5. Tests and communication: prototypes are evaluated by collecting opinions from users as well as experts on the problem at hand.

\section{Design Thinking Tools}

Design, as a multidisciplinary field, took its methods and tools from several knowledge fields, such as from the engineering, arts, economy, etc. But most of the visually related tools, such as sketching, mapping, prototyping, etc., stretch right back to the beginning of design education. These tools are enabling the designer to inquire about a future situation or solution to a problem and also serve to transform abstract immature and unrealized ideas into something to build on and to discuss with colleagues and other stakeholders (Tschimmel, 2012).

Design Thinking researchers agreed that certain assumptions define the Design Thinking approach such as iteration, ambiguity, visualization, collaboration, empathy, and satisficingthe abductive, non-linear nature of the process does not suggest a simple process model (Cross, 2006, Buchanan, 1992). Research demonstrated that Design Thinking involves creativity of thought and a willingness to accept uncertainty, Design Thinking is most often conducted in an extremely systematic way (Cross, 2001, 2006; Lawson, 2006).

Design thinking relies on the human ability to be intuitive, to recognize patterns, and to construct ideas that are emotionally meaningful as well as functional. The elements of design thinking combine to form an iterative approach - one you can try out and adapt to suit your needs. The design-thinking process brings team members together, focuses them on a shared and ambiguous goal.

\section{Tab. 1 How could Managers think like Designers?}

\begin{tabular}{|l|l|}
\hline Characteristics of Design Thinking Manager & $\begin{array}{l}\text { Characteristics of the traditional thinking } \\
\text { manager }\end{array}$ \\
\hline $\begin{array}{l}\text { Mainly visual, use of sketching and } \\
\text { prototyping tools }\end{array}$ & Mainly verbal, use of diagrams and tables \\
\hline $\begin{array}{l}\text { Intensive observation and } \\
\text { wondering, challenging stereotypical } \\
\text { subjective }\end{array}$ & $\begin{array}{l}\text { Immediate perception and quick interpretation of } \\
\text { a situation }\end{array}$ \\
\hline Abductive and inventive & Mainly rational and objective \\
\hline Failure is a part of the process & Analytical, deductive and inductive \\
\hline Comfortable with ambiguity and uncertainty & Looking for 'correct' answers \\
\hline $\begin{array}{l}\text { Empathic and human-driven, deep understanding } \\
\text { of peoples' needs and dreams }\end{array}$ & $\begin{array}{l}\text { Customer-driven, deep understanding about what } \\
\text { clients would like to have for their social status }\end{array}$ \\
\hline Principally collaborative & Principally individual \\
\hline
\end{tabular}

Source: In form Tschimmel, 2012, p. 20 


\section{METHODOLOGY}

Our aim is to introduce our knowledge and experience with soft skills development opportunities in education of top management in international environment, based on our participance in international project DT.UNI.-Design Thinking Approach for an Interdisciplinary University (DT.UNI)., where we participated at several workshops and courses on implementation of Design Thinking tools, and we have organized several of them. The main aim of the project is development of innovation in higher education institutions and is cofinanced via Erasmus+ Program.

Management staff is the key element of every university. Thanks to the project they have developed their skills, such as the ability to think in a divergent, creative, innovative, and interdisciplinary way, which is a core point of the project, become more open to changes at university, inter-cultural competences.

They took part in locally organized and international workshops, one of them took place in Birmingham in winter of 2018/2019.

In the next section we will bring you the evaluation of DT Uni Workshop for University Managers which took place in Birmingham in November 2018. For the measuring impact we have used Pre-test and Post-test surveys. There were 24 participants at the workshop, 20 of them fulfilled both Pre-test and Post-test.

Our respondents were between $30-62$ years old, $60 \%$ of them were women. Our participants were top managers and administrative staff at universities in several European countries Poland, Germany, Netherland, United Kingdom, Portugal, Iceland, Italy, and Slovakia.

$70 \%$ of our respondents were in management positions, $20 \%$ were in administration and 10 $\%$ were university teachers, associated professors or assistants of professors. Their former experience with Design Thinking varied from no experience to DT experts, $60 \%$ of them had some or no experience. They declared their current challenges that they face at their universities, they were similar - material equipment and working conditions, new challenges and strategies, new work models, they want to attract more students for their study programs, they have to work also with less skilled and unmotivated students, etc.

They expected that participation in the workshop will help them in everyday teamwork with different personalities, in exploiting the full potential of all team members and managing different tasks. They would like to learn useful tools to boost their creativity. They would like to know when and which Design Thinking tool to use and how to implement them in the process of teaching students. They also wanted to know the experiences of other people about implementing Design Thinking in their work.

\section{RESULTS AND DISCUSSION}

Results from our survey show, that workshops are effective way, how to develop soft skills of managers in international environment. Our survey was oriented to results of Pre-test and Post-test of workshop participants in Birmingham. These tests were in electronical forms, links to them were sent to each participant via e-mail, Pre-test was sent before workshop and link to Post-test was sent to them during last day of workshop. We have got 20 completed Pretests and Post-tests from 24 participants of the workshop, i.e. 83,33\%. This result we consider satisfactory.

Figures $1-3$ show respondents' views on selected claims related to their soft skill. We show some of them, that we consider most interesting. They indicated their perceptions on a scale 
of 1 to 5 , where 1 means that they don't currently do this very much and 5 means that this applies a lot/ always to how they currently work.

The Figure 1 shows, that dealing with complex problems and uncovering their different aspects may be also funny and interesting. We can see the change in the mindset of participants, which have more positive approach after the workshop, where several Design Thinking (DT) practices and tools were used with the aim to solve challenges by teams of participants in a funny and entertaining way. Managers need to deal with several complex problems in their work and creation of positive working atmosphere helps to uncover more ideas and lead to better results, including better working environment and satisfaction of employees.

Fig. 1 Respondents' views on claim "I have fun dealing with complex problems and uncovering their different aspects" (Number of responses)

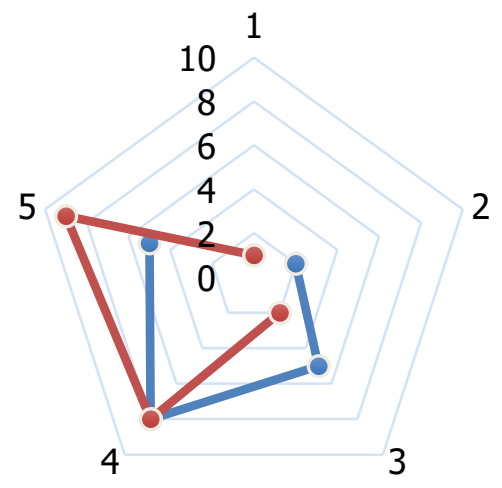

-0-Pre test

-๑-Post test

Source: DT Uni Survey in Birmingham, November 2018

We can see from this figure, that while in Pre-test only 1 participant gave 5 points to this statement, in Post-test there were 9, i.e. $45 \%$ of them. No-one neither in Pre-test, nor in Post-test gave only one point to this statement, from which we may conclude, that managers, researchers and teachers, naturally have some fun dealing with complex problems and uncovering their different aspects. All two participants, who gave only 2 points in Pre-test had changed their opinion after workshop, and found it more interesting, so nobody gave less than 3 points in the Post-test. $85 \%$ of participants after workshop gave 4 and 5 points, this result we consider as very positive.

The figure 2 shows the change in empathy of participants. Empathy is important part of communication skills and emotional intelligence.

Results from figure 2 show, that working in teams with people from other institutions and countries was more difficult, than expected. There were language and cultural differences, and it was necessary to find solutions to their given challenges. Only 3 participants perceived $\mathrm{him} /$ herself as perfect in this skill, 2 of them (10\%) put their evaluation by one level down in Post-test, from 3 to 2 points, 4 of them ( $25 \%)$ increased their self-confidence from 3 points to 4. 


\section{Fig. 2 Respondents' views on claim "I am very well able to anticipate what other people} think and feel (Number of responses)

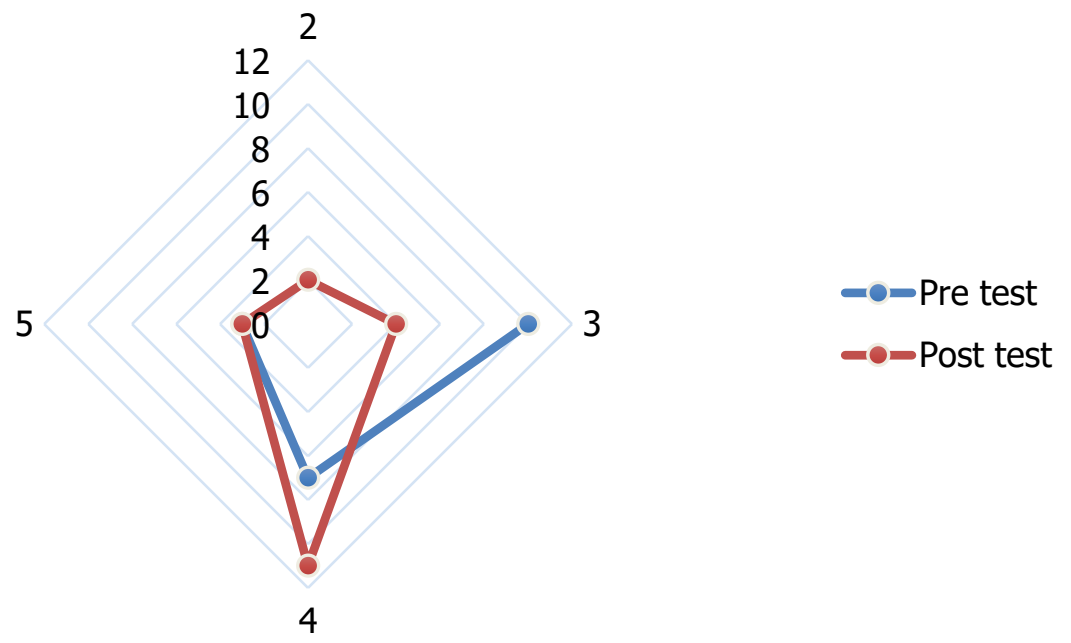

Source: DT Uni Survey in Birmingham, November 2018

Our experience is that we have not always guessed the right feelings of the other team members, which led to some misunderstandings, and in future we would like to be more careful. Design Thinking tools focused to train empathy helped participants to think more about what other people think and feel. Very interesting was activity "Explain to the Stranger". We were taken to the Museum of Art in Birmingham, as teams we had to choose a picture in the gallery, and we had to explain our solution of our challenge to the person on the picture. We had to brainstorm, what were feelings and fears of that person and we had to explain this person how our challenge may impact this person, and tell our solution in the way, that this person can understand and agree with it, that meant also to use language of the time period on picture.

The figure 3 shows positive changes of mindsets of participants related to enhance creativity soft skills. Creativity is perceived as very important soft skill and it is demanded to support it at workplace. There are several publications (Kerr, 2019, Khan, 2015, Koh et al., 2012, Laurillard, 2015, Filo, 2017, Tran, 2019), how to improve and develop it. During workshop we have used some of Design thinking tools, e.g. Brainstorming, Brainwriting, Persona, Letter to Grandma, etc.

Results in figure 3 show, that no one perceived him/herself as not good at spontaneously channelling their creativity to develop new ideas. The amount of less confident respondents in this area, who gave only 2 points, decreased from $4(25 \%)$ to $2(12,5 \%)$. On the other side, number of respondents who perceived themselves as perfect and very good at this skill (they gave 4 and 5 points) increased from $5(20 \%)$ to $13(65 \%)$, it more than tripled. We consider this result as perfect.

Our other research results showed, that after workshop participants feel less uncomfortable using concepts where they learn by doing $(-2 \%)$ and they have less trouble appreciating other perspectives $(-12 \%)$. They more rely on a certain methodological set of strategies $(+31 \%)$, they increased channelling of their creativity to develop new ideas by $19 \%$. They more enjoy exchanging and incorporating ideas and concepts from other team members $(+12 \%)$. 


\section{Fig. 3 Respondents' views on claim "I am very good at spontaneously channeling my} creativity to develop new ideas" (Number of responses)

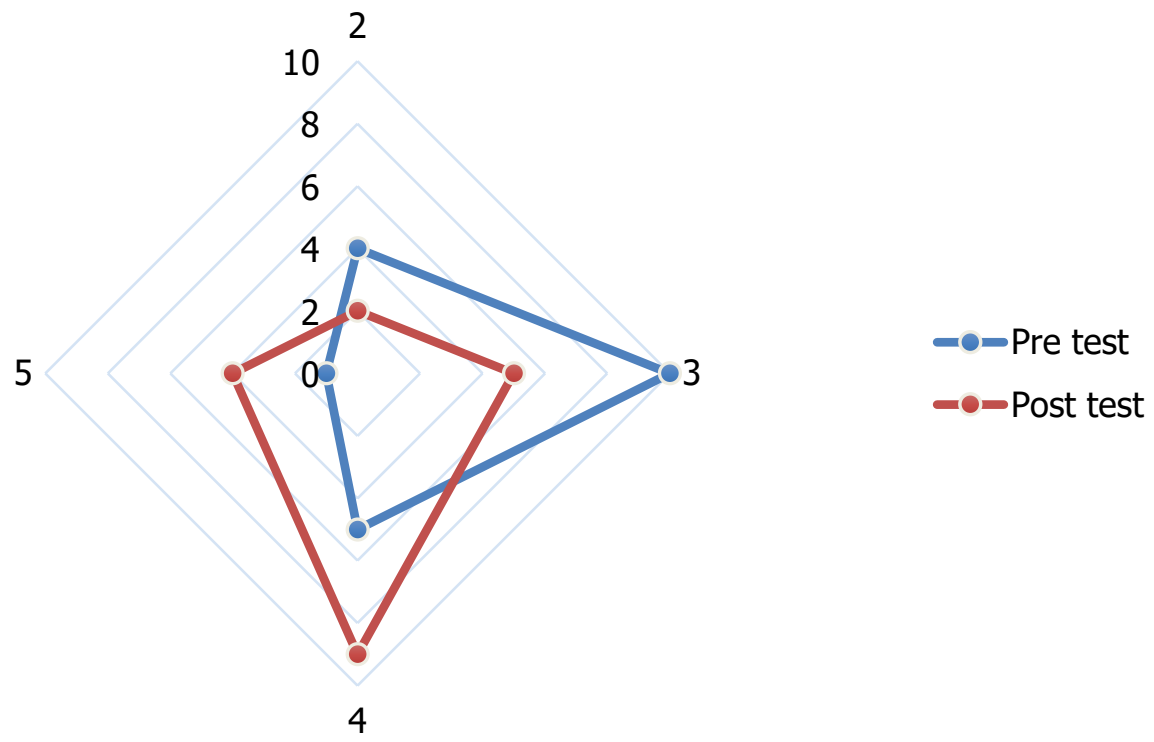

Source: DT Uni Survey in Birmingham, November 2018

The aim of use DT tools is also to improve soft skills of participants, e. g. patience, empathy, self-confidence and adaptability. Top improvement was obtained in use of certain strategies when being confronted with failure $(+23 \%)$ and in their enjoying developing a variety of ideas for one problem and having no trouble discarding them (+21\%). Design Thinking is focused to train people to be not afraid of bringing new ideas to the other team members, and to be not afraid to discard those ideas, that fail. People are afraid of failure and it blocks them in creativity. To achieve this, it is very important to create safe and positive atmosphere, where people share their ideas and build new ideas on ideas of the other team members. No idea is bad, criticism is forbidden, ideas are written on sticky notes and later they are selected by given criteria. Focus is on quantity of ideas, in given time limit, because it is known, that brain creates more ideas when it is under some pressure.

After workshop $75 \%$ of participants plan to encourage others to use DT processes in their work and only $5 \%$ declared, that they do not plan it. We have got also feedback, how to organize future workshops better. International environment of the workshop was perceived as very positive. Attendees could share their own experiences and their ideas of solving their challenges at their universities. They also improved their language skills in conversation and in teamwork. They have learned some useful tools to boost their creativity. They experienced several Design Thinking tools, so they can implement them in their managerial work.

Education of managerial skills via workshop we consider as good start for future selfdevelopment of managers. Mentoring may become the second step in the process of implementation of DT tools into managerial and teaching process. Some topics may be explained also via webinars and other online tools, that are effective and not complicated for use.

\section{CONCLUSION}

Design has always been a catalyst for innovation processes in product and service development. But over the last decade and more, emerged the concept Design Thinking by demonstrating that any kind of organisation can benefit from the designers' way of thinking 
and working, including management, business and educational institutions. After a stretching of the Design Thinking concept (Tschimmel, 2012; Johansson-Sköldberg, Woodilla \& Çetinkaya, 2013).

We have found that Design Thinking tools are useful also for managers, they enhance creativity, soft skills and they may lead to positive working atmosphere, and to better results. Participants plan to use DT approaches in their teaching process, in strategic processes, in teamwork, in managerial work, in the improvement of internal processes, in the process of seeking solutions to challenges, in designing new projects and in creation of new curricula. 75 $\%$ of them confirmed, that their specific lexicon had significantly increased. $95 \%$ of them agreed, that they practiced formulating questions in English. All participants practiced working in interdisciplinary / intercultural contexts.

Thinking like a designer helps managers to become aware of issues in a way that isn't very natural to other disciplines, and this can be especially helpful when users are involved. Design Thinking helps to understand issues and problems in a new context, and figure out how solutions will work in real-time.

The main goal of Design Thinking is to find the solution and promote innovation and creativity, but one of its big benefits is that it can help establish a strong and high-performing team.

Our own experience show, that Design thinking tools are not always applicable, and we carefully choose, when and where we will use them. Short workshops and trainings together with mentoring seem to be effective way, how to teach managers, how to develop their soft skills.

\section{REFERENCES}

Brown, T. (2009), Change by Design: How Design Thinking Transforms Organizations and Inspires Innovation. New York: Harper Collin.

Cassim, F. (2013), Hands on, hearts on, minds on: design thinking within an education context. Inter. J. of Art and Design Educ. (32), 190-202. https://doi.org/10.1111/j.14768070.2013.01752.x

Cross, N. (2011). Design Thinking: Understanding How Designers Think and Work. Oxford: Berg, ISBN-13: 978-1847886361.

Dinther, M., Dochy, F., \&Segers, M. (2011), Factors affecting students' self-efficacy in higher education. Educational Research Review, (6), 95-108. https://doi.org/10.1016/j.edurev.2010.10.003

Dunne, D. (2006). Design Thinking and how it will change Management Education: an Interview and Discussion with Roger Martin. Academy of Management Learning \& Education, 5 (4), 512-523. https://doi.org/10.5465/amle.2006.23473212

European Commission (2020). About higher education policy. Retrieved February 8 2021, from https://ec.europa.eu/education/policies/higher-education/about-higher-education-policy_en

Glen, R., Suciu, C., \& Baughn, C. (2014). The Need for Design Thinking in Business schools. Academy of Management Learning \& Education, 13 (4), 653- 667. https://doi.org/10.5465/amle.2012.0308

Johansson-Sköldber, U., Woodilla, J., \& Çetinkaya, M. (2013). Design Thinking: Past, Present and Possible Future. Creativity and Innovation Management, 22(2), 121-146. https://doi.org/10.1111/caim.12023 
Kerr, B. (2019). Creativity. Retrieved February 8 2021, from https://www.britannica.com/topic/creativity

Khairul, A. (2020). Future Job Trend in Design. IJISET - International Journal of Innovative Science, Engineering \& Technology, 7(5), 114 - 119, ISSN 2348 - 7968. Retrieved February 8 2021, from http://ijiset.com/vol7/v7s5/IJISET_V7_I5_11.pdf

Liedtka, J., \& Ogilvie, T. (2011). Designing for Growth - A Design Thinking Toolkit for Managers. Columbia University Press. 248. ISBN: 9780231158381.

Martin, R. (2009). The Design of Business. Why Design Thinking is the next Competitive Advantage. Boston, Massachusetts: In: Harvard Business Press. 208. ISBN: 9781422177808

OECD. (2020). OECD Skills Strategy Slovak Republic. Assessment and Recommendations. Retrieved February 10 2021, from https://www.oecd-ilibrary.org/education/oecd-skillsstrategy-slovak-republic_bb688e68-en

Paul, R., Hugo, R.J., \& Falls (2015). L.C., International expectations of engineering graduate attributes. Proc. 11th Inter. CDIO Conf., Chengdu, Sichuan, P.R. China. Retrieved February 8 2021, from http://www.cdio.org/files/document/cdio2015/95/95_Paper.pdf

Pombo, F., \& Tschimmel, K. (2005). Sapiens and demens in Design Thinking - Perception as Core. In Proceedings of the 6th International Conference of the European Academy of Design EAD'06. Bremen: University of the Arts Bremen. Retrieved February 7 2021, from https://www.researchgate.net/publication/228878635_Sapiens_and_demens_in_design_thin king-perception_as_core

Pruneau, D., El Jai, B., Dionne, L., Louis, N., \& Potvin, P. (2019), Design Thinking: What is it? In: Pruneau, D. (Ed), Design Thinking for Sustainable Development: Applied Models for Schools, Universities and Communities. Moncton, NB: Université de Moncton, Littoral et vie, 10-28. $\quad$ Retrieved February 7 2021, from https://lel.crires.ulaval.ca/sites/lel/files/educational_guide_design_thinkingcc.pdf

Pusca, D., \& Northwood, D.O. (2018), Curiosity, creativity and engineering education. Global J. of Engng. Educ.,20(3), 152-158. Retrieved January 12 2021, from https://www.researchgate.net/publication/333356362_Curiosity_creativity_and_engineering_ education

Renard, H. (2014), Cultivating design thinking in students through material inquiry. Inter. J. of Teaching and Learning in Higher Educ., 26, 414-424. Retrieved January 16 2021, from https://files.eric.ed.gov/fulltext/EJ1060903.pdf

Scheer, A., Noweski, C., \& Meinel, C. (2013), Transforming constructivist learning into action: design thinking in education. Design and Technol. Educ.: An Inter. J., 17, 8-19. Retrieved January $16 \quad 2021$, from https://www.researchgate.net/publication/332343908_Transforming_Constructivist_Learning _into_Action_Design_Thinking_in_education

Striebig, B., Ogundipe, A.A., \& Papadakis, M. (2016), Engineering Applications in Sustainable Design and Development. Boston, MA, USA: Cengage Learning. ISBN-13:9781133629788

Tschimmel, K. (2011). Design as a Perception-in-Action Process. In Taura, T., Nagai, Y., Design Creativity 2010. London: Springer Verlag, 223-230. https://doi.org/10.1007/978-0-85729-2247_29

Tschimmel, K. (2012). Design Thinking as an effective Toolkit for Innovation. In: Proceedings of the XXIII ISPIM Conference: Action for Innovation: Innovating from Experience. Barcelona. 1-10, ISBN 978-952-265-243-0. Retrieved January 16 2021, from 
https://www.academia.edu/1906407/Design_Thinking_as_an_effective_Toolkit_for_Innovati on

Tran, N. (2019). Design Thinking Playbook for change management in K12 schools. Retrieved $\begin{array}{lllll}\text { February } & 8 & 2021, & \text { from } & \text { https://dschool- }\end{array}$ old.stanford.edu/sandbox/groups/k12/wiki/ad2ce/attachments/3946e/DESIGN\%20THINKING \%20PLAYBOOK\%20\%281\%29.pdf?sessionID=8cbdfc6129ceb041dbad2247ffc9d0112fd0ebc e.

World Economic Forum (2019). 10 skills you'll need to survive the rise of automation. Retrieved February 8 2021, from https://www.weforum.org/agenda/2018/07/the-skills-needed-tosurvive-the-robot-invasion-of-the-workplace. 